Pro-Fil 22 (2) 2021: 28-44

https://doi.org/10.5817/pf21-2-2396

\title{
IRELEVANTNOSŤ TURINGOVHO TESTU V SÚČASNOM HLBOKOM UČENÍ
}

\author{
ONDREJ HRIADEL
}

\author{
Katedra filozofie a aplikovanej filozofie, Filozofická fakulta \\ Univerzity sv. Cyrila a Metoda v Trnave, Slovensko, ondro.hriadel@gmail.com \\ PŮVODNÍ VĚDECKÁ PRÁCE • OBDRŽENO: 9/9/2021 • PŘIJATO: 23/11/2021
}

\begin{abstract}
Abstrakt: Úlohou umelej inteligencie (UI) v Turingovom teste je imitovat' človeka do takej miery, aby vyšetrovatel' nebol schopný rozlíšit' stroj od človeka. S príchodom hlbokého učenia (DL) (podkategória UI) sa však situácia mení, pretože sa tieto systémy namiesto simulovania l'udskej inteligencie zameriavajú na riešenie konkrétnych problémov. $Z$ dôvodu, že tieto umelé systémy nesimulujú l'udskú inteligenciu, sa otvára otázka, či nie je Turingov test v problematike hlbokého učenia irelevantný. Na problém sa je možné pozriet'v troch častiach. Po prvé, sa je potrebné zamerat' na aplikačné využitie Turingovho testu v Loebnerovej cene, v ktorej sú kladené otázky zamerané na aspekty l'udskej inteligencie - učenie, usudzovanie a porozumenie. Po druhé, je možné považovat' za problém, že sa v Turingovom teste rozumie pod inteligenciou iba všeobecná l’udská inteligencia. Ked’že ani DL touto formou inteligencie nedisponuje, je možné bez pochýb označit' túto UI za neinteligentnú? Nakoniec je otázne, či by vlastne malo zmysel, aby účelovo zameraná UI, akou je DL, absolvovala Turingov test, nakol'ko samotný test žiadne d'alšie poznatky o analýze problémov alebo inteligencii neprináša.
\end{abstract}

Kl'účové slová: hlboké učenie (deep learning, DL); umelá inteligencia (UI); Turingov test; inteligencia; učenie; natrénovanie dát; jazyk

\section{THE IRRELEVANCE OF THE TURING TEST IN CURRENT DEEP LEARNING}

Abstract: The role of artificial intelligence in the Turing test is to imitate human beings to such an extent that people will not realize it is a machine. With the rise of deep learning (a subcategory of $\mathrm{AI}$ ), the situation is changing rapidly as the new systems do not focus on imitating human intelligence but emphasize thorough solutions to specific issues. The main difference between predefined AI and deep learning (DL) is that these systems are self-learning and have verifiable results. Firstly, we need to analyse the application of the Turing test in the Loebner Prize because, there, the primary emphasis is on aspects of human intelligence - learning, reasoning and understanding. Secondly, in the Turing test, only general intelligence is considered, and this can be questionable. If DL does not possess this form of intelligence, by this reasoning, we should consider it unintelligent. However, is such understanding correct? The third and last aspect questions whether the Turing test is beneficial for an AI designed for specific tasks because the results do not bring any new data and conclusions.

Keywords: deep learning (DL); artificial intelligence (AI); Turing test; intelligence; learning; training data; language 


\section{Úvod}

Z filozofického hl'adiska sa umelá inteligencia (d’alej len UI) vníma ako systém, ktorý by mal simulovat' alebo imitovat' l'udskú inteligenciu. S predstavou o inteligentných počítačoch prišiel už v roku 1950 Alan Turing. Zároveň ponúkol test (imitačnú hru), prostredníctvom ktorého by malo byt' možné odlíšit' strojovú entitu od l'udskej. Úlohou stroja v tomto teste je práve napodobit' človeka do takej miery, aby vyšetrovatel' (alebo aj porotcovia v novších verziách testu) nemohol odhalit', že komunikuje so strojom. S príchodom hlbokého učenia ${ }^{1}$ (d’alej len DL) sa situácia mení, nakol'ko sa tieto umelé systémy primárne nezameriavajú na simulovanie l'udskej inteligencie, ale na riešenie konkrétnych špecifických problémov bez nutnosti využívat' l'udské postupy. Na druhú stranu sa DL dokázalo v určitých činnostiach nielen vyrovnat' človeku, ale ho i prekonat' (napr. v hre GO). Z dôvodu, že ciel'om takejto UI nie je nutne simulovat' l'udskú inteligenciu, sa otvára problém, či Turingov test (ako test pre UI napodobujúcu l'udskú inteligenciu) nie je v problematike hlbokého učenia irelevantný.

Prvá čast' práce (2) sa bude zameriavat' na aplikačné využitie Turingovho testu v tzv. Loebnerovej cene ${ }^{2}$ (sút'až) v spojitosti s DL. Počas tejto sút’aže sa pri umelých systémoch zist'uje absencia alebo prítomnost' l'udských aspektov inteligencie, ktoré zahŕňajú kategórie učenie, usudzovanie a porozumenie. V súvislosti s DL sa možno v kategórii učenia zamerat' na metódu učenie s posilňovaním, u ktorej sa najpreukázatel'nejšie objavujú určité prvky učenia. Dôležitým bodom pri riešení tohto problému je zistit', či je možné uvádzanú metódu strojového učenia (d'alej len ML) považovat' za použitel'ný (i ked' nebiologický) model učenia, a to v komparácii s preddefinovanou UI nedisponujúcou žiadnym typom ML, ale i s l'udským učebným procesom. V kategórii usudzovania sa analýza bude sústred'ovat' na tri druhy usudzovania - dedukcia, indukcia, abdukcia. Hlavným problémom bude v tomto prípade to, či sú tieto druhy v DL aplikované a akým spôsobom i v súvislosti s človekom. Porozumenie je aj u DL problematickým aspektom, nakol'ko nie je možné jasne identifikovat', čo to znamená, že „UI rozumie“. Napriek tomu sa nevylučuje možnost', že DL disponuje určitým stupňom (alebo formou) porozumenia, vzhl'adom na to, že nie je preddefinovaným, ale učiacim sa systémom, i ked' forma porozumenia nemusí striktne korešpondovat's l'udskou predstavou tohto aspektu. Na základe uvádzaných troch kategórií sa objavuje možnost' irelevantnosti Turingovho testu v problematike hlbokého učenia, a to $\mathrm{z}$ dôvodu, že tieto kategórie nemusia byt' striktne chápané iba v spojitosti s l'udskou inteligenciou, ale i s inými umelými systémami využívajúcimi odlišné postupy než človek. Rozoberanú tézu zároveň môžu podporit’ aj dve nasledujúce časti, ktoré celý problém dopĺńajú.

Druhá čast' (3) sa bude venovat' otázke, či je v spojitosti s Turingovým testom možné považovat' DL za neinteligentné. V Turingovom teste sa predpokladá, že UI bude simulovat' všeobecnú l'udskú inteligenciu, nakol'ko sa má čo najviac pripodobnit' človeku, aby úspešne absolvovala túto skúšku. Ked’že sa DL nepokúša a ani nedisponuje schopnost’ami, ktorými by sa vyrovnala l'udskej inteligencii, je možné považovat' tieto umelé systémy automaticky za neinteligentné, alebo test chápe inteligenciu nesprávnym spôsobom?

Tretia čast' (4) sa zameria na pozíciu umelých systémov v Turingovom teste. Preddefinované chatboty sú priamo zamerané na absolvovanie takýchto testov, nakol'ko majú naprogramovaný

\footnotetext{
${ }^{1}$ Hlboké učenie (deep learning, DL) založené na viacvrstvových neurónových siet'ach je podkategóriou strojového učenia (machine learning, ML), ktoré je jedným z odvetví v umelej inteligencii (UI) (pozri Chollet 2019).

${ }^{2}$ Loebnerova cena je každoročná sút'až umelej inteligencie zameraná na konverzáciu v l’udskom jazyku. Založená bola v roku 1990 Hughom Loebnerom, po ktorom je aj pomenovaná. Sút’až prebieha na základe ,štandardného Turingovho testu“ (Turing 1950).
} 
bežný repertoár l'udských výpovedí. DL so zameraním na trénovanie jazyka môže mat' vzhl'adom na množstvo natrénovaných dát (a prepracovanost' algoritmu) preto výhodu v porovnaní so štandardným chatbotom. Na druhú stranu je otázne, aký zmysel by malo, aby takáto UI absolvovala Turingov test, ked’že sa primárne zameriava na trénovanie štrukturálnych aspektov jazyka, na ktoré samotný test odpovede neprináša.

\section{Turingov test $\mathrm{v}$ súčasnej umelej inteligencii}

Alan Turing vo svojom článku Počítacie stroje a inteligencia predstavuje tézu o mysliacich strojoch, ktoré sa svojou inteligenciou vyrovnajú bežnému racionálnemu človeku. Turing sa však v práci nezaoberá analýzou l'udskej inteligencie a ani inteligenciou všeobecne. Namiesto toho ponúka test, prostredníctvom ktorého by malo byt' možné odlíšit' strojovú entitu od l'udskej. Pôvodne bol tento test (tzv. imitačná hra) považovaný skôr za myšlienkový experiment než za reálnu skúšku strojovej inteligencie. A to prevažne z toho dôvodu, že v dobe, v ktorej Turing žil, bol vrcholom technológie mechanický výpočtový stroj, a nie digitálny počítač alebo UI. Zásadná zmena prišla so založením Loebnerovej ceny - sút’aže, ktorá Turingov experiment aplikovala ako plnohodnotný test. Na základe neho je možné odhalit' prítomnost' alebo absenciu l'udských aspektov inteligencie u tzv. chatbotov, čiže UI zameranej na konverzáciu v l'udskom jazyku.

Vývoj UI sa ale postupne začína zameriavat' na pokročilejšie druhy tejto technológie, ktoré odsúvajú záujem o chatboty do vedl'ajšej pozície, ked’že sú naprogramované iba na „hranie“ v Loebnerovej cene bez žiadneho d’alšieho účelu. Dôležitým míl'nikom a zároveň jedným z hlavných smerov vývoja UI sa v súčasnosti stáva technológia hlbokého učenia, ktorého metódy a ciele sa diametrálne líšia od štandardných chatbotov. DL sa primárne nepokúša simulovat' l'udskú inteligenciu, naopak je účelovo zamerané a natrénované na jednu konkrétnu úlohu (napr. AlphaGO na hranie hry GO). Dokonca je nutné dodat', že v súčasnosti ani nie je plnohodnotná simulácia možná, nakol'ko sa vývoj ani nepribližuje k úplnému porozumeniu aspektov l'udskej inteligencie. Odborník na umelú inteligenciu M. Jordan v rozhovore s L. Gomesom dokonca tvrdí, že: „neurovedy sú d’aleko od riešenia, akým spôsobom sa l'udský mozog učí, tým pádom ani metódy hlbokého učenia nemôžu mat' žiadnu priamu spojitost' s biologickým učením“(Gomes 2014).

\section{Účelová umelá inteligencia}

Už v roku 1998 Ford a Hayes predpokladali, že lepší prístup k vývoju UI bude vtedy, ked’ „opustíme ciel' vytvorit' program imitujúci l’udskú inteligenciu a namiesto toho sa zameriame na systémy nevyžadujúce podobný prístup“ (Ford - Hayes 1998, 80). Vzhl’adom na súčasný stav umelej inteligencie je možné tento predpoklad považovat' za správny. Zároveň sa ukazuje, že existujú i odlišné prístupy k riešeniu UI, ktoré sú efektívne aplikovatel’né aj v súčasnosti. $\mathrm{Z}$ toho dôvodu by mala aj filozofia zaujat' nové stanovisko $\mathrm{k}$ tejto problematike. To znamená, že okrem neustáleho argumentovania a odôvodenia možnosti „umelej l'udskej inteligencie“ (humanlike) je potrebné prijat' aj novú kategóriu „umelej účelovej inteligencie“, do ktorej by bolo možné zaradit' aj DL, nakol'ko sa primárne nesnaží simulovat' biologický model učenia. Práve naopak, prichádza s novými metódami, ktoré sa so spomínaným modelom priamo nespájajú. V súvislosti s navrhnutým stanoviskom je nutné prehodnotit’ relevanciu Turingovho testu v súčasnej UI, nakol'ko ide z hl'adiska filozofie mysle o prvú teóriu, ktorá otvorila problematiku mysliacich strojov. Ked’že sa test postupne vytráca zo súčasného filozofického diskurzu, zostáva už iba otázka, či má miesto v aktuálnych problémoch UI, alebo je i pre DL bezvýznamný. Konkrétne sa v nasledujúcich pasážach budem zaoberat' atribútmi inteligencie zist'ovanými 
prostredníctvom Turingovho testu, na základe ktorých sa pokúsim poukázat', že v metódach DL zohrávajú značne inú úlohu v porovnaní s l'udskou inteligenciou. Prípadne, že ich analýza pomocou tejto technológie ani nevyžaduje. Tým sa zároveň budem snažit' poukázat' na možnost', že Turingov test je v problematike hlbokého učenia irelevantný.

Predtým než budem pokračovat', by som rád zmienil niekol'ko krátkych pripomienok. Nemám záujem v tejto práci poukazovat' na všeobecnú bezvýznamnost' Turingovho testu, nakol'ko je možné, že v budúcnosti bude existovat' UI, pre ktorú sa stane vhodnou skúškou inteligencie (napr. UI so štruktúrou identickou s l’udským mozgom). Na druhú stranu sa chcem vyhnút špekuláciám, ktoré nekorešpondujú s aktuálnym výskumom. Z tohto dôvodu aj (aktuálne) navrhujem pragmatickejšie stanovisko účelovej umelej inteligencie.

\section{Učenie, usudzovanie a porozumenie v hlbokom učení}

V Loebnerovej cene sa počas Turingovho testu zist'uje prítomnost' alebo absencia aspektov inteligencie (prostredníctvom kladených otázok), ktoré zahŕňajú učenie, usudzovanie a porozumenie. Na ich základe by malo byt' možné rozlíšit' l'udskú entitu od strojovej. James Moor argumentuje, že „práve tieto kategórie sú perfektne spojené s l’udskou inteligenciou“. Zároveň tvrdí, že „nejde o nezávislé kategórie, ale práve naopak navzájom prepojené“ (Moor 2001, 8788). S druhou čast'ou argumentu je možné súhlasit', a to aj v súvislosti s DL. V prípade tejto UI ide dokonca o hierarchické prepojenie, nakol'ko usudzovanie a porozumenie sú závislé od procesu učenia. Prvá čast' argumentu je problematickejšia. Moor vo svojej práci nepredpokladá dve (aktuálne) klúčové možnosti, ktoré by sa v rámci problematiky hlbokého učenia mohli objavit'. Po prvé, neberie v úvahu existenciu UI, ktorá by žiadnym spôsobom nesimulovala a ani nenapodobňovala l'udskú inteligenciu. Po druhé, považuje uvedené kategórie za striktné aspekty l'udskej inteligencie, čo je v súčasnosti možné označit' minimálne za nepresné hl'adisko. Na objasnenie tohto problému sa je nutné podrobnejšie pozriet' na konkrétne kategórie, a to v rámci metód, ktoré DL využíva pri riešení úloh.

\section{Kategória: učenie}

Kl'účovou metódou, ktorú DL využíva pri riešení úloh, je tzv. učenie s posilňovaním. ${ }^{3}$ Prostredníctvom tejto metódy je schopné počas riešenia problému vykonat' tri dôležité kroky: natrénovat' surové dáta, samostatne optimalizovat' dáta (UI si je v podstate sama sebe súperom, napr. AlphaGO hrala proti sebe hru GO) a nakoniec spätne si opravit' chyby (spätné šírenie chyby). Yamins a DiCarlo podotýkajú, že „takýto učiaci proces sa zdá byt’ bytostne odlišný od všetkého, čo je spojené s biologickým vývojom alebo l'udskou kultúrou“ (Yamins - DiCarlo 2016,364). Na prvý pohl'ad sa zdá, že ide o relevantný názor. Najmä z dôvodu, že DL vykonáva učenie v uzavretom prostredí zameranom na jeden konkrétny problém. Inými slovami UI je (nebiologicky) kognitívne uzavretá ${ }^{4} \mathrm{v}$ riešení špecifického problému v súlade $\mathrm{s}$ natrénovanými dátami, čo je diametrálne odlišné od l'udského spôsobu riešenia problémov. Overenie hypotézy, že metóda učenie s posilňovaním je skutočne odlišná od biologického modelu učenia, vyžaduje dva prístupy. Po prvé je nutné konfrontovat' postupy DL so štandardnou UI, ktorá nevyužíva žiadne princípy ML. Na základe toho sa dá potvrdit', že je zmieňovaná metóda reálne použitel'ným modelom učenia. Druhým krokom je jej porovnanie s l'udskými postupmi, na základe čoho sa preukáže podobnost' alebo odlišnost' DL, a l’udskej inteligencie v kategórii „učenie“.

\footnotetext{
${ }^{3}$ Okrem učenia s posilňovaním (reinforcement learning) sa medzi základné metódy strojového učenia (vrátane DL) ešte zarad'uje učenie s učitel'om (supervised learning) a učenie bez učitel'a (unsupervised learning).

${ }^{4}$ Okrem prípadov, kedy sa využíva tzv. učenia s prenosom (transfer learning), prostredníctvom ktorého je možné natrénovanú neurónovú siet' použit’ aj na riešenie súvisiacich podobných problémov (pozri Tan et al. 2018).
} 


\section{Klasická umelá inteligencia}

Predchodcovia DL, ktorí nevyužívali žiadnu formu ML, disponovali iba preddefinovaným naprogramovaním. To síce znamenalo, že takáto UI bola schopná vykonat' úlohu, na ktorú bola nastavaná, no na druhú stranu u nej absentovala možnost' samostatnosti či učenie sa z reprezentácie dát, ${ }^{5}$ ktorá by prispela k podrobnejšiemu riešeniu určitého problému. Išlo vlastne o program, ktorého algoritmy nijakým spôsobom neaplikujú učebné prvky, a to i v prípade, že daná UI zdanlivo zvládala úlohy na l'udskej úrovni. Ukážkovým príkladom takéhoto druhu UI je Deep Blue, ktorý síce dokázal porazit' v šachovom dueli majstra sveta Garyho Kasparova, avšak iba na základe matematicky najpravdepodobnejších t'ahov. Skutočnost', že Deep Blue nedisponuje žiadnymi učebnými prvkami, potvrdzuje aj Schubbach: „Funkčnost' Deep Blue bola definovaná formálnymi algoritmami v programovacom jazyku C“ (Schubbach 2019, 1810), ktorý sa práve používa na preddefinované kódovanie. Zároveň sa ukazuje, že ciel’om tejto UI bolo iba ukázat', ako technológia tej doby a preddefinované kódovanie dokáže porazit' človeka, avšak bez potreby vytvárat' niečo nové. Dokonca aj Hsu, jeden z programátorov Deep Blue, hovorí: „Vedel som presne aké hardvérové hodnotenie bolo nastavené v každej hre“ (Hsu 2004, 200). Týmto tvrdením vlastne potvrdzuje preddefinovanost' krokov, ktoré Deep Blue vykonával počas hry. Na základe zmienených dôvodov možno usúdit', že tento druh UI neprináša pri analýze nič nové okrem toho, čo už do nej vložili tvorcovia. V takomto prípade nie je možné hovorit' o tom, že by podobná UI disponovala určitou formou modelu učenia, nakol'ko sa ani v jej postupoch neobjavujú znaky, ktoré by tomuto atribútu zodpovedali.

\section{Učenie v hlbokom učení}

Výhodou DL na rozdiel od predchádzajúceho variantu je už zmieňovaná metóda učenia s posilňovaním, ktorá ju oslobodzuje od nutnosti disponovat’ preddefinovaným naprogramovaním. Uvádzané tri kroky (natrénovanie dát, samostatná optimalizácia dát a spätná oprava chýb), ktoré sú integrálnou súčast'ou metódy, zároveň poukazujú na možnú samostatnost' a učebné prvky v procese trénovania. Otázkou ostáva, či je takýto postup možné považovat' za použitel'ný (i ked' nebiologický) model učenia. Relevantným zástupcom UI s DL je práve AlphaGO, ${ }^{6}$ na základe ktorej bude možné preukázat', či je metóda učenie s posilňovaním reálne použitel'ným modelom učenia. Ked’že zmieňované tri kroky sú v metóde klúčové, rozbor problému bude pokračovat' bližším pohl'adom priamo na ne.

V prvom kroku AlphaGO natrénovala značné množstvo dát, ktoré obsahovali pravidlá a postupy hry GO, a čo je dôležité, duely odohrané l’udskými hráčmi (dáta približne z 1000 hier). Hned' tu sa je potrebné zastavit' a všimnút' si zásadné odlišnosti v porovnaní s Deep Blue. AlphaGO sa na rozdiel od Deep Blue prispôsobuje počas natrénovania hernému prostrediu, nejde preto primárne iba o využitie matematicky najpravdepodobnejšieho t'ahu, ale skôr využitie dát ako „skúsenosti“ $\mathrm{k}$ d’alšej aplikácii. López-Rubio uvádza, že ide vlastne o ,adaptáciu dát

\footnotetext{
${ }^{5}$ Spôsob, akým sa v neurónovej sieti nahliada na dáta (ako ich DL vidí). Obrázky môžu byt' reprezentované napr. v pixeloch alebo RGB. Ide o jeden z dôležitých algoritmov DL, na ktorom závisí správnost' výstupu (pozri Bengio et al 2013).

${ }^{6} \mathrm{Z}$ technického hladiska je ešte potrebné upresnit', že AlphaGO mala okrem algoritmu učenie s posilňovaním implementované aj d'alšie algoritmy - učenie s učitel'om, vyhl'adávací algoritmus Monte Carlo, hodnotiacu siet' (value network) a ešte niekol'ko d’alších. To znamená, že jednotlivé kroky a celkovo celý proces natrénovania nezávisel iba na jednej metóde, ale na kombinovanom použití algoritmov (pozri Silver, D. - Huang, A. - Maddison, C. et al. 2016). Zároveň ale možno dodat', že učenie s posilňovaním je jednou s klúčových metód, na ktoré sa zameriava výskumný program od Google „DeepMind“ zaoberajúci sa vývojom DL, ako je AlphaGO, AlphaGOZero či AlphaStar.
} 
k čo najlepšej sumarizácii problému“ (López-Rubio 2018, 671). Netreba ale zabúdat', že pojem skúsenost' sa $\mathrm{v}$ tomto prípade musí chápat' striktne v spojení s dátami, ktoré má DL k dispozícii. Najmä z dôvodu, že AlphaGO je (nebiologicky) kognitívne uzavretá v pravidlách a postupoch hry $\mathrm{z}$ natrénovaných dát, $\mathrm{v}$ ktorých síce vyniká, avšak nezrovnalosti nekorešpondujúce $\mathrm{s}$ hernými mechanizmami sú pre ňu neriešitel'né (pozri Hriadel 2020). I ked' AlphaGO podlieha určitým obmedzeniam, v porovnaní s Deep Blue ide o nezanedbatel'ný pokrok, nakol'ko je schopná použitel'ným spôsobom zosumarizovat' dáta, čo je zároveň u nej iba začiatkom riešenia, a nie finálnym stavom.

Ak by bolo možné nazvat' prvý krok jedným slovom „sumarizácia“, druhý by sa bez problémov dal označit’ ako „optimalizácia“, ked’že po natrénovaní dát ich bola AlphaGO schopná plnohodnotne využit'. To sa prejavilo tým, že si samostatne nasimulovala herné duely, v ktorých hrala proti sebe samej. Zároveň zužitkovala nadobudnuté znalosti herných kombinácií, na základe ktorých vytvorila vlastné potenciálne výherné stratégie. V tomto bode sa ukazuje, že DL je schopné nadviazat' a asociovat' predchádzajúce znalosti a tým si vytvorit' vlastné poznatky, ktoré neboli vopred naprogramované. Niekto by síce mohol povedat', že tieto schopnosti jej boli dané vd’aka algoritmu, to by bol však nepresný názor, pretože algoritmus jej slúžil skôr ako šablóna podobne ako aj človeku. Treba aj dodat', že takýto prístup k riešeniu úlohy je unikátnym práve pre hlboké učenie. López-Rubio túto skutočnost' výborne konštatuje: „Automatické učenie je revolučným atribútom hlbokého učenia, nakol'ko si takáto UI dokáže samostatne vybrat' optimálnu možnost'." (López-Rubio 2018, 673) Tým sa taktiež snaží naznačit', že v jednoduchších typoch strojového učenia (napr. plytkom učení ${ }^{7}$ ) táto vlastnost' absentuje (samozrejme to isté platí aj pre UI akou je Deep Blue). Zároveň tým poukazuje na samostatnost', ktorá sa objavuje výhradne v algoritmoch DL.

Tretí krok - spätné šírenie chyby ${ }^{8}$ - by sa bez problémov mohol spojit' s predchádzajúcim, nakol'ko sú vykonávané v podstate súčasne. I ked' by sa na prvý pohl'ad mohlo zdat', že ide už iba o dodatkovú vlastnost', nie je to tak, pretože je dôležitá pri finálnom konštruovaní stratégie. Presnejšie povedané, AlphaGO prostredníctvom tohto algoritmu znížila chybovost' vo svojich postupoch (konkrétne úpravou parametrov siete - váh), čo ju nakoniec doviedlo k výhernej stratégii, ktorou porazila v roku 2016 majstra sveta v hre GO Lee Sedola. Pravdepodobne aj preto ju Fitch nazýva „srdcom hlbokého učenia“ (Fitch 2014). Nakol'ko je spätné šírenie chyby priamo prepojené $\mathrm{s}$ druhým krokom (samostatná optimalizácia dát), taktiež ide o výsadnú vlastnost' hlbokého učenia. Ako sa ukázalo, výsledok celého procesu natrénovania možno pokladat' za značný úspech, nakol'ko AlphaGO vytvorila t'ahovú stratégiu, ktorá nebola nikdy vykonaná človekom. Tým sa preukázalo, že aj pomocou umelých metód učenia je možné prekonat' človeka v činnostiach, ktoré majú k tomu ešte naviac aj vel'mi dlhú tradíciu (hra GO vznikla približne v roku 2000 pred n. 1.).

Na základe uvedených krokov je zjavné, že metóda učenie s posilňovaním prináša postup riešenia problémov s učebnými prvkami, ktorý je možné považovat' za reálny a použitel'ný model učenia, a nie iba za preddefinované naprogramovanie. Relevantnost' tézy podporuje aj skutočnost', že preukázaný model učenia prináša výsledky, na základe ktorých je DL nielen schopné porazit' človeka v určitých činnostiach, ale dokonca vytvorit' aj niečo nové a neočakávané. Po predstavení vyššie spomínaného stanoviska treba konštatovat', že aj v technológii hlbokého učenia sa objavuje použitel’ný model učenia. Vyvstáva ešte otázka, či je tento model učenia skutočne odlišný od l'udského, alebo sa v ňom nachádzajú určité podobnosti.

\footnotetext{
${ }^{7}$ Shallow learning.

${ }^{8}$ Spätné šírenie chyby (Error backpropagation alebo iba backpropagation ) je z technického hl'adiska algoritmus, ktorého úlohou je v neurónovej sieti znízit' chybovost' z predchádzajúcich vrstiev.
} 


\section{Komparácia s človekom}

Levesque argumentuje, že sú dva hlavne spôsoby, akými sa človek môže učit'. Po prvé ide o „učenie zo skúsenosti, ktoré spája aj s tréningovým procesom“. V druhom prípade hovorí o „učení prostredníctvom jazyka, ktoré zase spája s kontextom a naratívnom“(Levesque 2017). Na prvý pohl'ad by sa mohlo zdat', že sa v prvom prípade objavujú náznaky podobnosti. Druhý postup je naopak v súvislosti s UI (aj DL) problematický. Na základe predložených východiskových bodov sa je teraz nutné pozriet' na problém podrobnejšie z pohl'adu oboch spôsobov a zároveň v spojitosti s postupmi DL, ktoré boli rozoberané v predchádzajúcich pasážach.

Učenie zo skúsenosti je s človekom späté od útleho detstva, ked’že mu pre nadobudnutie znalostí touto cestou postačujú zmysly a interakcia s vonkajším svetom. Na rozdiel od prvotnej skúsenosti učenie prostredníctvom tréningového procesu vyžaduje k nadobudnutiu určitej zručnosti opakovaný prístup. Zároveň však každý potvrdí, že ide o vel'mi prirodzenú cestu, ako sa niečo naučit'. Akákol'vek UI (vrátane DL) primárne nedisponuje hardvérom, ktorý by slúžil $\mathrm{k}$ adaptácii na vonkajšie prostredie. Dokonca $\mathrm{v}$ prípade DL je takýto doplnok úplne irelevantný, nakol'ko sú jej algoritmy zamerané na učenie dát špecifického problému, a nie na interakciu s vonkajším svetom. ${ }^{9}$ To principiálne vylučuje podobnost' DL modelu učenia s l'udským.

Zdanlivo najvýraznejšia podobnost' sa objavuje v učení na základe tréningového procesu. Je možné spomenút' niekol'ko kl'účových rozdielov, na základe ktorých bude možné preukázat', že v skutočnosti je táto domnienka nepresná alebo nepravdivá. Po prvé, i ked' sa v oboch prístupoch učenia (u človeka a DL) objavuje pojem skúsenost', jej použitie je iné. Človek nevyužíva enormné množstvo dát, aby sa zdokonalil v určitej zručnosti, namiesto toho spolieha na opakované pokusy, prostredníctvom ktorých sa postupne zlepšuje. DL naopak na sumarizáciu určitého problému (čiže vytvorenie „skúsenosti“ využitej na riešenie úlohy) vyžaduje vel'ké množstvo dát, inak by nebola schopná vykonávat' d'alšie kroky. ${ }^{10}$ Po druhé, DL je schopné vykonávat' spätnú opravu chýb v celej neurónovej sietí, aby minimalizovala chybovost'. V tomto bode je nutné povedat', že aj človek nepochybne vie spätne opravit' svoje chyby, z ktorých sa poučí. Nie je však striktne viazaný na naučené dáta, v ktorých by hl'adal potenciálne nezrovnalosti. Tréningový proces u človeka je skôr postavený na pokusoch a omyloch. Fitch túto diferenciu trefne komentuje: „Spätná oprava chýb je biologicky plauzibilná, nie však na úrovni neurónovej siete“ (Fitch 2014, 340). Po tretie, človek sa ani nepribližuje úrovni kognitívnej kapacity, ktorá by mu umožňovala samostatne vytvárat' riešenia (napr. stratégie), pri ktorých by si mohol byt' simultánne aj oponentom, tak ako je schopná DL (tým zároveň nechcem povedat', že by si človek v žiadnom prípade nemohol byt' oponentom). V súvislosti s nastolenými rozdielmi sa nakoniec ukazuje, že zdanlivá podobnost' je mylným názorom. Je zjavné, že sa tréningové procesy u človeka a DL neporovnatel'ne líšia. Dokonca je možné povedat', že sú to dva odlišné učebné postupy.

Učenie prostredníctvom jazyka je aj v súčasnosti nezlučitel'né s postupmi UI, a to i v prípade, že je možné hovorit' o použitel'nom modeli učenia, ked’že v prípade DL sú vstupné dáta

\footnotetext{
${ }^{9}$ Tým nechcem povedat', že trénované dáta nemôžu byt' o vonkajšom svete. Práve naopak. Dáta sa vzt'ahujú k riešenému problému (napr. dáta v podobe cestných záznamov, jazykové nahrávky, texty či dáta o hre). Samotné natrénovanie však prebieha na počítačoch s výkonným hardvérom s mnohými GPU a CPU. Integrácia (čiže konkrétne použitie) napr. u áut prebieha až po natrénovaní, a nie v aute.

${ }^{10}$ Výnimkou je jednorazové učenie (one shot learning), ktoré vyžaduje menšie množstvo dát (pozri Vinyals et al. 2016). I ked’ stále nejde o konceptuálne učenie podobné človeku, tento prístup je tomu najbližšie. Na druhú stranu zatial' neprináša zatial' také výsledky (aj aplikačné využitie) ako DL využívajúce vel'ké databázy.
} 
natrénované štatistickým spôsobom. U l’udí je samozrejme situácia úplne iná, či už ide o prijímanie znalostí z kontextového porozumenia, alebo prostredníctvom naratívu. Možnost' využívat' sémantiku umožňuje človeku priame učenie bez nutnosti vykonat' hlbšiu analýzu, a to iba prostredníctvom vel'mi malého počtu informácií (napr. jedno slovo). Goulden a jeho kolegovia napr. uvádzajú, že ,diet'a sa je schopné naučit' novú znalost' už na základe niekol'kých slov a fráz" (Goulden et al. 1990). Ako som už uvádzal, DL by v takejto situácii nebolo schopné vykonávat' natrénovanie, ked'že $\mathrm{k}$ tomu vyžaduje enormné množstvo dát. Nechcem tu hovorit' o tom, že ked' UI nedisponuje sémantikou, nemôže ani mysliet'. Zároveň nesúhlasím, aby sa inteligencia striktne spájala s myslením, ked’že sa ukázalo, že môže fungovat' použitel'ný model učenia aj bez l'udských atribútov. Namiesto toho navrhujem, aby sa deficit sémantiky nepovažoval nutne za nevýhodu, na základe ktorej mnohí ešte aj dnes označujú UI za neužitočný nástroj. Ide len o iný prístup riešenia problémov využivajúci štatistické metódy namiesto sémantického prístupu, ktorý však prináša výsledky bez potreby vyniknút' v myšlienkovom experimente (argument čínskej izby) (pozri Searle 1994). Ide však o úplne iný problém, ktorý priamo nekorešponduje s aktuálnou témou, preto ho nateraz nechávam otvorený.

Zdá sa, že odlišnosti medzi l'udským a umelým modelom učenia sú natol'ko zjavné, že oba modely je nutné považovat' za samostatne použitel'né. Preukázalo sa, že umelý model učenia implikuje učebné prvky a postupy prinášajúce nepopieratel'né výsledky. Niet pochýb, že DL spíňa kategóriu „učenie“ bez nutnosti integrácie alebo simulovania l'udských aspektov učenia, ktoré sú diametrálne odlišné od postupov prostredníctvom metódy učenia s posilňovaním.

\section{Kategória: usudzovanie}

Problematike usudzovania v DL (ale i všeobecne v ML) sa nevenuje tol'ko pozornosti ako učeniu (trénovaniu dát). Dôvodom môže byt' to, že tvorcovia DL sa zväčša zaoberajú iba algoritmami či neurónovými siet’ami, ostatné aspekty však opomínajú. Ako aj upozorňuje Zhou, „strojové učenie a logické uvažovanie sú v histórii UI skúmané oddelene“ (Zhou 2019, 1). Napriek oddelenému výskumu sa niekol'ko počítačových vedcov zaoberá aplikáciou indukcie a abdukcie v ML (Zhou 2019; Kakas - Michael 2020; Mooney 2000; Nguifo 1998). Na základe toho sa pokúsim v tejto časti poukázat' na opodstatnenost' týchto druhov usudzovania v DL. Zároveň rozoberiem, prečo sa tretí druh usudzovania - dedukcia - s postupmi DL nespája.

\section{Dedukcia}

Z psychologického hl'adiska l'udia využívajú všetky druhy usudzovania intuitívne. Dokonca nemusia ani vediet', ktoré z nich v danú chvíl'u použili (ak neberieme v úvahu výskum v logike). Na rozdiel od človeka DL pracuje prostredníctvom presných komputačných postupov, ktoré úplne l'udskú intuíciu nezahrňujú. Jednou z úloh, ktorú DL vykonáva počas trénovania, je zovšeobecnenie kontextu, z ktorého môže následne predikovat' nové dáta. Ked’že je výsledkom detektívneho usudzovania opak a zároveň DL prijíma prvotné dáta, ktoré nie sú zovšeobecnené, dedukcia by v takomto kroku nemala žiadne využitie. Nadväzujúcim problémom je, že dedukcia neprináša novú vedomost'. Oterllo konkrétne uvádza, že „dedukcia vedomosti odvodzuje, indukcia a abdukcia môžu priniest' nové poznatky“ (Oterllo 2013, 56). Pokial' je úlohou DL predikovat' či vytvárat' nové dáta (a tým aj poznatky), dedukcia ani túto podmienku nespíňa. Zároveň sa tým objasňuje, prečo sa mnohí zameriavajú na výskum indukcie a abdukcie $\mathrm{v}$ ML, a nie na tento druh usudzovania. 


\section{Indukcia}

Za predpokladu, že indukcia a abdukcia sú súčast'ou postupov ML, treba objasnit' ich konkrétnu úlohu v procese natrénovania. Podl'a Facha a Kakasa „nededuktívne druhy usudzovania vykonávajú v UI dva základné procesy - explanáciu a zovšeobecňovanie“(Flach - Kakas 2000, 15). Ako už bolo naznačené, jedným z postupov DL je práve zovšeobecnit' trénované dáta. Presnejšie je to možné rozviest' tak, že čiastkovou úlohou v DL je v prijatých dátach nájst' relevantné vzorky informácii, z ktorých môže vytvorit' všeobecné okruhy, a z tých generovat' nové výsledky, čiže dáta vzt'ahujúce sa k riešenému problému. Napriek tomu, že celý proces nezodpovedá induktívnemu uvažovaniu, je možné na základe Nguifovmu výkladu indukcie „entita - fakt - overenie vlastnosti - fakt - zovšeobecnie faktov“ (Nguifo 1998, 2) - usúdit', že určitá čast' trénovania je induktívna.

\section{Abdukcia}

Abdukcia je proces vytvárania explanácii (hypotéz) z pozorovaných dát. V porovnaní s predchádzajúcimi druhmi usudzovania ide o menej známy logický proces. Na druhú stranu v problematike ML sa viacerí autori zameriavajú prevažne na abdukciu (autori spomínaní vyššie). Prečo je práve abduktivné usudzovanie dôležité pri trénovaní dát, napovedá argument Kakasa a Michaela: „Abduktívne usudzovanie môže byt' použité na vyplnenie medzier u nekompletných vzoriek dát prostredníctvom informatívnych hypotéz o ich hodnotách, čím pomáha pripravit' tréningové dáta na proces učenia“ (Kakas - Michael 2020,10). Uvádzaný argument je klúčový z dvoch dôvod. Po prvé, implicitne poukazuje na skutočnost', že abdukcia v ML predchádza indukcii. To podporujú aj etapy vedeckého skúmania, v ktorých generovanie hypotéz (abdukcia) zohráva prvú úlohu (Fach - Kakas 2000, 6, 7). Po druhé, napovedá akú úlohu zohráva abduktívne usudzovanie $\mathrm{v}$ trénovaní dát. Ked’že sa prostredníctvom abdukcie vytvárajú explanačné hypotézy z pozorovaných (prijatých) dát, možno usúdit', že v ML zastupujú základné vzorky znalostí, ktoré sa následne induktívnym usudzovaním zovšeobecňujú.

Ako naznačuje posledná veta, medzi indukciou a abdukciou existuje i v ML určitý vzt'ah, ktorý možno rozdelit' do dvoch kontinuálne sa opakujúcich etáp. Za prvú etapu možno označit' už zmieňované prepojenie, pri ktorom sa $\mathrm{z}$ výstupu abduktívneho usudzovania stáva vstup pre induktívne, pomocou ktorého sa relevantné dáta (hypotézy) zovšeobecnia do nových znalostí. Druhá etapa môže nastat' $\mathrm{v}$ prípade, ak sú dáta aktualizované, prípadne nekompletné. To znamená, že proces prebieha dovtedy, pokial' spracovanie dát nie je dostatočné. Flach a Kakas (2000) aj Kakas a Michael (2020) sa zhodujú, že ide o tzv. cyklus abduktívneho a induktívneho rozvoja vedomostí. ${ }^{11}$

Na základe analýzy troch druhov usudzovania v súvislosti s DL sa ukázalo, že procesy prostredníctvom dedukcie nekorešpondujú s postupmi počas trénovania dát. Na druhú stranu sa niektoré kroky, ktoré DL vykonáva, ukázali ako induktívne. Posledný druh usudzovania - abdukcia - zohráva taktiež dôležitú úlohu v procese trénovania, nakol'ko pripravuje základné vzorky znalosti, t. j. hypotézy, ktorá sa d'alej prostredníctvom indukcie zovšeobecňujú. Zároveň je potrebné skonštatovat', že medzi indukciou a abdukciou existuje v DL vzt'ah nazývaný cyklus abduktívneho a induktívneho rozvoja vedomostí. V súvislosti človekom je nakoniec možné uviest', že v prípade DL nejde o intuitívne využívanie usudzovania, ale viazané na proces natrénovania dát.

\footnotetext{
${ }^{11}$ The cycle of abductive and inductive knowledge development.
} 


\section{Kategória: porozumenie}

Kategóriu „porozumenia“ je i v súvislosti s DL možné označit’ za funkcionalistickú čiernu skrinku (black box) ${ }^{12}$ nakol'ko nie je jasne identifikovatel'né, čo vlastne znamená, že „UI rozumie“. Samozrejme, problém sa môže spájat' s vyžadovaním explanácie. UI nie je schopná nijakým spôsobom vysvetlit', prečo práve vykonala ten určitý krok. Zároveň je nutné dodat', že by sa jej to nepodarilo spôsobom, ktorý by bol pre l'udí prijatel'ný a zrozumitel'ný. Ludia na druhú stranu vyžadujú explanáciu ako dôkaz, že tomu, čo hovoria, skutočne rozumejú, a to na základe významov. Vynára sa otázka, či aj v DL, ktoré na rozdiel od preddefinovaných programov disponuje preukázatel'ným modelom učenia, ale aj formami usudzovania, skutočne neexistuje schopnost' porozumenia alebo je diametrálne odlišná od l'udského variantu. Druhá možnost' sa zdá byt' vzhl'adom na predchádzajúce dve kategórie pravdepodobnejšia.

Existujú dozaista l'udia, ktorí bez problémov chápu komplexné matematické operácie a zároveň ovládajú niekol'ko numerických sústav. Na základe toho dokážu vytvárat' a analyzovat' počítačové algoritmy. Nie je to však bežný spôsob, akým sa prijímajú či konštruujú nové informácie. Na rozdiel od UI sú l'udia uspôsobení na poznávanie prostredníctvom sémantického používania jazyka (a skúsenosti), čomu aj prispôsobujú prostredie, v ktorom žijú, a to v globálnom hl’adisku. Pre DL prostredie nepredstavuje celý svet plný významov, ale natrénovanú neurónovú siet', na ktorú je primerane optimalizované a dokáže v nej vykonávat' náležité kroky (na základe algoritmov). Ako uvádzajú Kruger a jeho kolegovia, „z každej vrstvy je vyextrahovaná vlastnost', ktorá je adaptovaná na nasledujúcu vrstvu s komplexnejšou vyextrahovanou vlastnost’ou, než mala predchádzajúca“" (Kruger et al. 2013, 1864, 1865). Na základe Krugerových slov je možné usúdit', že DL dokáže vytvárat' v neurónovej sieti reprezentácie, s ktorými môže štrukturálne (vrstva nadväzuje na vrstvu) zaobchádzat'. I ked' ani Krugerova téza nedokazuje, že by bolo DL schopné rozumiet' jednotlivým krokom, ktoré vykonáva. Minimálne upozorňuje na skutočnost', že v neurónových siet'ach sa vykonávajú komplexnejšie kognitívne operácie než v prípade klasickej UI.

\section{Project Debater}

Pravdepodobne jeden z najt’ažších kognitívnych úkonov a zároveň výziev vo výskume UI je komunikácia s človekom, a to nie len vo forme odpovedí na otázky, ale i plynulej diskusie na určitú tému. V tomto odvetví zatial' dosiahol najväčší úspech Project Debater od IBM, ktorý dokázal absolvovat' v roku 2019 argumentačný duel proti l'udskému súperovi. Ako uvádzajú tvorcovia projektu, „Project Debater bol schopný prostredníctvom metód „t'ažba argumentov“ (argument mining) určit’ relevantné argumenty a protiargumenty v rámci všetkých natrénovaných textov, pomocou AKB vyselektovat' najrelevantnejšie argumenty pre jednotlivé druhý diskusií, t. j. vybrat' najvhodnejšie argumenty priamo na diskusiu. Na základe metódy „vyvrátenia argumentu“" (argument rebuttal) predpokladat' tvrdenia oponenta a vytvorit' na ne odpoved' a nakoniec pomocou ,konštrukcie diskusie“ (debate construction) vytvorit' argumentačnú reč“ (Slonim, N. - Bilu, Y. - Alzate, C. et al. 2021, 380). Project Debater síce nedokáže používat' jazyk takou formou ako l'udia (sémantika), prostredníctvom uvádzaných metód sa však ukazuje, že existujú aj iné spôsoby, ako hodnotit' kvalitu a konštruovat' argumenty (Toledo et al. 2019). V súvislosti s problémom porozumenia sa je možné na proces pozriet' $\mathrm{z}$ dvoch strán. Po prvé, ked’že Project Debater nedisponuje rovnakými schopnosti ani hardvérom ako človek, ktorý by umožňoval porozumiet' argumentom a celému procesu diskusie, nie je schopný porozumenia. Po druhé, pokial' mu jednotlivé metódy umožňujú pracovat's textami, na základe

\footnotetext{
${ }^{12} \mathrm{Z}$ funkcionalistického hl'adiska je čierna skrinka (black box) mysel' (alebo UI program), u ktorej nie sú známe vnútorné mechanizmy, ale iba vstupné a výstupné informácie.
} 
ktorých je schopný hodnotit' i vytvárat' argumenty v rámci celej diskusie, nie je možné minimálne z funkcionalistického hl'adiska určitú úroveň porozumenia vylúčit'.

Na rozdiel od predchádzajúcich dvoch kategórií (učenie a usudzovanie) je porozumenie v DL inherentnejším aspektom, ktorý nemá žiadne zjavné podobnosti s človekom. Vyžadovanie explanácie ako dôkaz porozumenia je bežnou záležitost'ou v prípade sémantickej formy. V neurónovej sieti a súčasných jazykových systémoch sa však objavujú metódy, v ktorých by bolo možné určitý stupeň porozumenia predpokladat', alebo ho minimálne úplne nevylučujú.

Na základe prezentovaných zistení možno konštatovat', že existujú zásadné rozdiely medzi l'udskou inteligenciou a DL. Napriek uvedeným odlišnostiam je i tak zjavné, že DL disponuje atribútmi, ktoré mu umožňujú vykonávat' proces trénovania dát bez nutnosti aplikovat' prvky l'udskej inteligencie.

V súvislosti s analyzovanými kategóriami využívanými v Turingovom teste na odlíšenie strojovej a l'udskej entity je možné usúdit', že ich síce DL spĺn̆a, avšak úplne iným spôsobom, ako sa predpokladá v tomto teste, ked’že sa považujú za striktne l'udské aspekty, ktoré by mal adept na úspešné absolvovanie testu simulovat' podl'a človeka. $Z$ účelového hl'adiska je DL úplne odlišným systémom, ktorý prináša iné spôsoby riešenia problémov namiesto simulovania l'udskej inteligencie, a to i v rámci uvedených kategórií. $Z$ tohto dôvodu je Turingov test v spojitosti s problematikou hlbokého učenia možné považovat' minimálne za irelevantný.

\section{Nízka kognitívna úroveň hlbokého učenia}

V Turingovom teste sa predpokladá, že UI bude simulovat' l'udskú inteligenciu, ktorú možno označit' ako všeobecnú. Inými slovami, človeku jeho inteligencia umožňuje nielen učit' sa z jazyka a skúsenosti, ale i utvárat' spomienky a asociovat' ich s novými myšlienkami, vyznávat' určité náboženstvo, zaradit' sa do nejakého kultúrneho celku atd'. Pokial' UI nie je schopná reagovat' a odpovedat' na otázky z týchto alebo podobných oblastí, je označená za neinteligentnú. French na odhalenie nízkej kognitívnej úrovne u UI (neschopnost' sa vyrovnat' l'udskej inteligencii) vytvára niekol'ko subkognitívnych otázok, ktoré podl'a neho nedokáže zodpovedat' žiadny umelý systém. Napr. ,Je slovo Flugblogs vhodné použit’ ako názov novej počítačovej spoločnosti? Je slovo Flugly vhodné na pomenovanie detského plyšového medvedíka?“13 (French 1990, 59). Pravdepodobne ani najlepšia UI zameraná na spracovanie prirodzeného jazyka by nepodala uspokojivú odpoved' porovnatel'nú s človekom, nakol'ko tie slová neexistujú v štandardnej slovnej zásobe. Človek je na druhú stranu schopný podobné výrazy asociovat' so slovami, ktoré už má vo svojej slovnej zásobe, dokonca ich môže spojit's nejakou št'astnou alebo smutnou spomienkou. Na základe toho nakoniec dokáže podat' uspokojivú odpoved’, s ktorou by každý pravdepodobne súhlasil a považoval ju za „’udskú“. Znamená to, že máme UI a konkrétne DL považovat' za neinteligentné? Pravdepodobne nie.

\section{Inteligencia v hlbokom učení?}

Problém je v samotnom pojme „inteligencia“, ktorý je častokrát striktne a i nesprávne spájaný iba s l’udským myslením a celým jeho kognitívnym systémom. Parnas napr. tvrdí, že

\footnotetext{
${ }^{13}$ French d'alej aplikuje subkognotívne otázky do tzv. hodnotiacej hry (rating game), v ktorej sa má hodnotit' vhodnost' neologizmov v otázkach od 0 (kompletne neprijatel'né) do 10 (kompletne prijatel'né). Človek prostredníctvom sémantického prepojenia (napr. flugly - ugly) alebo kultúrnej asociácie dokáže výrazy vzhl'adom na položené otázky bez problémov zhodnotit'. Umelá inteligencia by s tým (bez zmieňovaných kognitívnych dispozícií) mohla mat' problém (French 1990).
} 
akákol’vek UI nemá s inteligenciou nič spoločné: „Inteligentná UI je iba ilúziou, vytvorenou z nesprávneho porozumenia významu pojmu inteligencia, ktorý môže mylne naznačovat', že UI ma blízko k l'udskej inteligencii.“ (Parnas 2017, 31) Práve na Parnasových slovách sa ukazuje, ako vel'mi si l'udia privilegujú a privlastňujú atribút „byt' inteligentný“. Zároveň sa s týmto hl'adiskom spája problém, že l'udia chápu dispozíciu inteligencie binárne, bez možnosti uvažovat' o iných formách inteligencie. Inak povedané, bud' ňou nejaká entita disponuje, alebo nie. Súhlasím, že preddefinovaná UI skutočne nie je inteligentná, ked’že ide skôr o program vykonávajúci presne nastavené kroky bez náznakov inteligencie. V prípade DL však s týmto názorom nemožno súhlasit'. V predchádzajúcich častiach sa totiž ukázalo, že tento typ UI je schopný vykonávat' komplexné procesy zahŕňajúce učenie, usudzovanie i určitý stupeň porozumenia, ktoré je možné považovat' za preukázatel'né znaky inteligencie. Súčasné DL by bolo možné považovat' za neinteligentné iba v prípade, že by sa pokúšalo pripodobňovat' l'udskej inteligencii (presnejšie povedané, bolo by ho možné označit' za neinteligentné v porovnaní s človekom). $\mathrm{O}$ to sa však ani nesnaží. Namiesto toho je účelovo natrénované na riešenie konkrétnych problémov, v ktorých prináša preukázatel'né výsledky. Z toho je možné usúdit', že DL disponuje formou inteligencie, ktorá je dostatočná na riešenie problémov, na ktoré je primárne zameraná.

Ako sa ukázalo, v Turingovom teste je inteligencia chápaná nesprávnym spôsobom, nakol'ko sa $\mathrm{v}$ n̆om redukuje iba na l'udskú inteligenciu a neberie $\mathrm{v}$ úvahu d'alšie potenciálne formy. Ked’že sa však v DL objavujú preukázatel'né znaky inteligencie, niet pochýb, že táto UI určitou formou inteligencie disponuje. To podporuje aj skutočnost', že použité procesy prinášajú náležité výsledky v rámci riešeného problému. Skutočnost', že DL disponuje formou inteligencie, ktorá sa nijakým spôsobom nesnaží pripodobňovat' l'udskej, stavia Turingov test opät' do pozície, v ktorej je pre túto UI pravdepodobne irelevantný.

\section{Pozícia hlbokého učenia v Turingovom teste}

Chatboty s preddefinovaným naprogramovaním pravdepodobne nebudú mat' nikdy všestrannejšie využitie než len sút’aženie v „testoch inteligencie“"založených na Turingovom teste. Iná situácia nastáva v prípade chatbotov založených na technológii hlbokého učenia, ktorá nie je viazaná na podobné naprogramovanie, ale naopak na natrénovanie dát. To im zretel'ne prináša väčší potenciál aj v trénovaní jazyka (presnejší názov pre túto UI znie DL zamerané na spracovanie prirodzeného jazyka), podobne ako u AlphyGO v hre GO. Takouto UI je napr. GPT-3, ktorý ešte nedosahuje l'udskú úroveň v otázke používania jazyka. Ako uvádza Lacker, zvláda ,základy logiky (logických otázok) a je schopný využívat' zdravý rozum (common sense)“" (Lacker 2020). Nemám záujem hovorit’ o tom, ako blízko je l’udskej inteligencii, nakol'ko by to aktuálne ani nemalo význam. Samotná UI je totiž iba v začiatočnej beta verzii. Zároveň tento problém priamo nekorešponduje s témou štúdie. Namiesto toho sa zameriam na problém, do akých pozícií to stavia túto UI (a i d’alšie podobné systémy zamerané na spracovávanie prirodzeného jazyka), a to i v súvislosti s Turingovým testom.

Po prvé, vyvstáva otázka, či má zmysel, aby podobné UI absolvovali imitačnú hru, nakol'ko aj Turing redukuje možnost' myslenia či inteligencie v umelých systémoch na ,úspešné absolvovanie imitačnej hry“ (Turing 1950). Samozrejme, natrénované DL by malo v porovnaní s preddefinovanom UI väčšiu šancu na úspech, nakol'ko by bolo schopné aktívne pristupovat' a simultánne využívat' vel'ké množstvo dát. Princíp by však zostal rovnaký, a to oklamat' vypočúvajúceho vyšetrovatel'a, eventuálne aj porotu v novších variantoch Turingovho testu. Nijakým spôsobom by sa $\mathrm{v}$ tomto teste nereflektovali postupy alebo i odlišná forma inteligencie $\mathrm{v}$ rámci DL, nakol'ko by sa predpokladalo, že testovaný systém musí simulovat' l'udskú inteligenciu. 
Výsledkom by bolo iba odhalenie alebo neodhalenie (v prípade úspechu) funkcionalistickej „čiernej skrinky“ bez žiadneho d’alšieho prínosu.

Na druhú stranu, účelové využitie a presná reprezentácia dát prostredníctvom metód DL nielenže prináša výsledky, umožňuje aj riešenia vel'mi špecifických problémov, na ktoré človek nemá kognitívnu kapacitu. Plytké pripodobňovanie sa človeku je možno signifikantné v rámci myšlienkového testu imitačnej hry, v skutočnosti to však neprináša nič nové na rozdiel od riešenia rôznych úloh (vrátane jazykových) prostredníctvom postupov DL. French napríklad argumentuje, že „niektoré situácie (interakcia so svetom) vyžadujú zapojenie l’udských zmyslov“ (French 2000, 119). Tým upozorňuje na obmedzené kognitívne schopnosti UI. S týmto tvrdením možno súhlasit', je ale nutné dodat', že podobný deficit by nebol schopný odhalit' ani Turingov test. Napriek kognitívnym obmedzeniam je DL schopné vykonávat' postupy, na ktoré je určené, a to i v prípade spracovania prirodzeného jazyka. Samozrejme by neprinieslo a nebolo schopné adaptovat' poznatky so situácií, s ktorými sa človek bežne stretáva. DL zamerané na spracovanie prirodzeného jazyka sa však sústred’uje na štrukturálnu stránku problému, a nie na l'udské skúsenosti.

Ak by bolo DL zamerané na spracovanie prirodzeného jazyka stávané do pozície, v ktorej by malo iba absolvovat' Turingov test, neprinieslo by to nič nové. Záver testu by priniesol iba odhalenie či neodhalenie systému, ktorý by bol stále považovaný za „čiernu skrinku“ bez žiadnej d’alšej reflexie potenciálne odlišnej formy inteligencie. $Z$ účelovej pozície však DL prichádza s rôznymi možnost'ami využitia (komunikácia v l'udskom jazyku, hlasový asistenti, rozpoznávanie reči atd'.), a to bez nutnosti simulovat' l'udskú inteligenciu v imitačnej hre, čo by i tak neprinieslo žiadny d'alší prínos okrem úspechu v tomto myšlienkovom experimente.

\section{Záver}

Turingov test je pravdepodobne vhodnou skúškou inteligencie pre systémy, ktoré sú naň priamo naprogramované. Na druhú stranu ho nie je možné ponímat' ako všeobecný test pre akýkol'vek umelý systém, ked’že práve v metódach súčasného DL sa objavujú aspekty, ktoré nemajú so simulovaním l'udskej inteligencie priamu súvislost'.

Tri kategórie inteligencie - učenie, usudzovanie a porozumenie - zist'ované v aplikačnom využití Turingovho testu v rámci Loebnerovej ceny síce tieto umelé systémy spíňajú (alebo nimi disponujú), avšak odlišným spôsobom než človek. DL oproti preddefinovaným systémom disponuje použitel'ným (i ked' nebiologickým) modelom učenia sa na základe metódy učenie s posilňovaním. V porovnaní s človekom má však diametrálne odlišný kognitívny (nebiologický) postup najmä s dôrazom na množstvo naučených informácií (v prípade UI dát). Kl'účové druhy usudzovania sú v DL abdukcia a indukcia. Prostredníctvom abdukcie sa z prijatých dát vytvárajú základné vzorky znalostí (hypotézy), ktoré sú následne zovšeobecnené pomocou induktívneho usudzovania. Zároveň medzi týmito dvoma druhmi usudzovania existuje vzt'ah, ktorý im umožňuje pri aktualizácii eventuálne nekompletnosti dát celý proces opakovat', pokial' nebude stav dát dostatočný na trénovanie. Dedukcia v trénovaní dát nemá konkrétne využitie, nakol'ko je dôležitým krokom v tomto procese zovšeobecňovanie, ktoré deduktívne uvažovanie neumožňuje. I ked' sa v tomto prípade objavuje zjavná podobnost' s človekom, je potrebné zmienit', že l'udia využívajú všetky druhy usudzovania intuitívne bez potreby špecificky analyzovat', ktorý druh usudzovania použit'. Využitie konkrétnych druhov usudzovania však v DL korešponduje s komputačnými metódami ML. Porozumenie v DL i tak nie je jasne identifikovatel'né. Nie je ani možné s istotou povedat', že táto UI žiadnym spôsobom „nerozumie“. Aj ked’ nejde o porozumenie na základe sémantickej formy jazyka, ukázalo sa, že v prostredí a v metódach DL 
prebiehajú procesy, ktoré schopnost' porozumenia úplné nevylučujú, i ked' diametrálne odlišným spôsobom ako sa predpokladá u človeka. Analýza uvádzaných troch kategórí ukázala, že možnost' irelevantnosti Turingovho testu v problematike hlbokého učenia nie je vylúčená. Rozbor nasledujúcich dvoch problémov poukázal na aspekty, ktoré relevantnost' tézy d'alej podporujú.

Všeobecná inteligencia l'ud'om umožňuje riešit' viacero rozličných problémov, ale i chápat' svet a vlastný život spôsobmi, ktoré nie sú striktne viazané na naučené informácie. To však neznamená, že inteligencia musí byt' ponímaná iba binárne. Inými slovami či ňou entita disponuje, alebo nie. Ked'že je DL zamerané na riešenie konkrétnych problémov prostredníctvom metód ML s učebným procesom, nesmie byt' bez pochybností označené za neinteligentné. Na rozdiel od človeka DL nepotrebuje (a ani nemá možnost') pri trénovaní brat' do úvahy nuansy vonkajšieho sveta, nakol'ko by aj k riešeniu konkrétneho problému mohli byt' irelevantné. V súvislosti s metódami ML je možné inteligenciu v tejto UI ponímat' ako inú úroveň alebo formu, ktorá je optimalizovaná na riešenie problémov, v ktorých prináša výsledky, a to aj na nadl'udskej úrovni.

DL zamerané na spracovanie prirodzeného jazyka oproti chatbotom naprogramovaným $\mathrm{k}$ absolvovaniu Turingovho testu môže priniest' výsledky v podobe aplikačného použitia (integrácia do umelých systémov využívajúcich l'udský jazyk či reč). Za predpokladu, že by aj táto UI bola schopná absolvovat' Turingov test (dokonca by mohla mat' výhodu v súvislosti s natrénovanými dátami), neprinieslo by to žiadne d'alšie poznatky o možných formách alebo úrovniach inteligencie, okrem odhalenia či neodhalenia ,čiernej skrinky“، Z tohto dôvodu pre účelovo ponímané DL, ktoré prináša výsledky v spracovávaní jazyka, nemá zmysel absolvovat' Turingov test, nakol'ko by to bol v konečnom dôsledku iba d'alší problém, na ktorý by muselo byt' natrénované.

Na základe rozoberaných problémov je možné považovat' Turingov test v súčasnej UI založenej na DL za irelevantný. Situácia by sa síce mohla zmenit', keby neurovedy dokázali replikovat' l'udský mozog a jeho vlastnosti. V súvislosti s aktuálnym vývojom UI je však irelevantnost' Turingovho testu v problematike hlbokého učenia preukázatel'nou možnost'ou.

\section{Pod'akovanie:}

Tento príspevok vznikol vd’aka podpore APVV-17-0064 - Analýza multidimenzionálnej podoby trans- a posthumanizmu.

\section{Bibliografia}

Bengio, Y. (2013): Representation Learning: A Review and New Perspectives, IEEE Transactions on Pattern Analysis and Machine Intelligence 35(8), 1-30, dostupné z: $<$ 10.1109/TPAMI.2013.50 >.

Fitch, W. T. (2014): Toward a computational framework for cognitive biology: Unifying approaches from cognitive neuroscience and comparative cognition, Physics of Life Reviews 11(3), 329-364, dostupné z: < https://doi.org/10.1016/j.plrev.2014.04.005 >.

Flach, P. A. - Kakas, A. C. (2000): Abductive and Inductive Reasoning: Background and Issues, in Flach, P. A. - Kakas, A. C. (eds.) Abduction and Induction. Applied Logic Series 18, 1-27, dostupné z: < https://doi.org/10.1007/978-94-017-0606-3_1 >. 
Ford, K. M. - Hayes, P. J. (1998): On Computational Wings: Rethinking the Goals of Artificial Intelligence, Scientific American Presents 9, 78-83.

French, R. M. (1990): Subcognition and the Limits of the Turing Test, Mind 99(393), 53-65, dostupné z: < https://doi.org/10.1093/mind/XCIX.393.53>.

French, R. M. (2000): The Turing Test: The First 50 Years, Trends in Cognitive Sciences 4(3), 115-122, dostupné z: < https://doi.org/10.1016/S1364-6613(00)01453-4 >.

Gomes, L. (2014): Machine-Learning Maestro Michael Jordan on the Delusions of Big Data and Other Huge Engineering Efforts, IEEE Spectrum [online], 2014-10-20, [cit. 2021-03-31], dostupné z: < https://spectrum.ieee.org/machinelearning-maestro-michael-jordan-on-the-delusions-of-big-data-and-other-huge-engineering-efforts $>$.

Goulden, R. - Nation, P. - Read, J. (1990): How Large Can a Receptive Vocabulary Be? Applied Linguistics 11(4), 341-363, dostupné z: < https://doi.org/10.1093/applin/11.4.341 >.

Hriadel, O. (2020): Kognitívna (ne)uzavretost' umelej inteligencie (Deep Learning), in Cintula, I. - Mydlová K. - Kalivodová, V. (eds.) LOQUERE: interdisciplinárna doktorandská konferencia: zbornik príspevkov, Univerzita sv. Cyrila a Metoda v Trnave, 105-117.

Hsu, F-H. (2004): Behind Deep Blue: Building the Computer that Defeated the World Chess Champion, Princeton University Press.

Chollet, F. (2019): Deep learning v jazyku Python, Grada.

Kakas, A. - Michael, L. (2020): Abduction and Argumentation for Explainable Machine Learning: A Position Survey, Cornell University arXiv.org > cs > arXiv:2010.12896, 1-24, dostupné z: < https://arxiv.org/abs/2010.12896 >.

Kruger, N. et al. (2013): Deep Hierarchies in the Primate Visual Cortex: What Can We Learn for Computer Vision?, IEEE Transactions on Pattern Analysis and Machine Intelligence 35(8), 1847-1871, dostupné z: < 10.1109/TPAMI.2012.272 >.

Lacker, K. (2020): Giving GPT-3 a Turing Test, Kevin Lacker's blog [online], 2020-07-06, [cit. 2021-03-31], dostupné z: < https://lacker.io/ai/2020/07/06/giving-gpt-3-a-turingtest.html >.

Levesque , H. J. (2017): Common Sense, the Turing Test, and the Quest for Real AI, The MIT Press.

López-Rubio, E. (2018): Computational Functionalism for the Deep Learning Era, Minds and machines 28, 667-688, dostupné $\mathrm{z}$ : < https://doi.org/10.1007/s11023-018-9480-7 >.

Mooney R. J. (2000): Integrating Abduction and Induction in Machine Learning, in Flach, P. A. - Kakas, A. C. (eds.) Abduction and Induction. Applied Logic Series 18, 181-191, dostupné z: < https://doi.org/10.1007/978-94-017-0606-3_12 >. 
Moor, J. H. (2001): The Status and Future of the Turing Test, Minds and Machines 11, 77-93, dostupné z: < https://doi.org/10.1023/A:1011218925467 >.

Nguifo, E. M. (1998): Abduction and Induction in Learning Task: which needs the other? ACADEMIA - Accelerating the world's research 1-3, dostupné $\mathrm{z}$ :

$<$ https://scholar.google.com/scholar?hl=sk\&as_sdt=0\%2C $5 \& \mathrm{q}=$ Abduction+and+Induction+in+Learning+Task\%3A+which+needs+the+other+\%3F\&btnG $=>$.

Otterlo, M. V. (2013): A Machine Learning View on Profiling, Privacy, Due Process and the Computational Turn The Philosophy of Law Meets the Philosophy of Technology, 41-65, dostupné z: < https://doi.org/10.4324/9780203427644 >.

Parnas, D. L. (2017): The real risks of artificial intelligence, Communications of the ACM 60(10), 27-31, dostupné z: < https://doi.org/10.1145/3132724 >.

Searle, J. (1984): Mysl, mozek a věda, Mladá fronta, 1994.

Schubbach, A. (2019): Judging machines: philosophical aspects of deep learning, Synthese 198, 1807-1827, dostupné z: < https://doi.org/10.1007/s11229-019-02167-z >.

Silver, D. - Huang, A. - Maddison, C. et al. (2016): Mastering the game of Go with deep neural networks and tree search, Nature 529, 484-489, dostupné z: < https://doi.org/10.1038/nature16961 >.

Slonim, N. - Bilu, Y. - Alzate, C. et al. (2021): An autonomous debating system, Nature 591, 379-384, dostupné z: < https://doi.org/10.1038/s41586-021-03215-w >.

Tan C. et al. (2018): A Survey on Deep Transfer Learning, in Kůrková V. et al. (eds.) Artificial Neural Networks and Machine Learning - ICANN 2018. Lecture Notes in Computer Science 11141, 270-279, dostupné z: < https://doi.org/10.1007/978-3-030-01424-7_27 >.

Toledo, A. et al. (2019): Automatic Argument Quality Assessment - New Datasets and Methods, Proceedings of the 2019 Conference on Empirical Methods in Natural Language Processing and the 9th International Joint Conference on Natural Language Processing (EMNLP-IJCNLP), D19-1564, 5625-5635, dostupné z: < https://doi.org/10.18653/v1/D19$1564>$.

Turing, A. (1950): Počítacie stroje a inteligencia, Medzinárodná účastnícka spoločnost’ Bradlo, 1992.

Turing, A. (1950): Computing Machinery and Intelligence. Mind 59(236), 433-460, dostupné z: < https://doi.org/10.1093/mind/LIX.236.433 >.

Vinyals, O. et al. (2016): Matching Networks for One Shot Learning, Advances in Neural Information Processing Systems 29, 1-12, dostupné z: < https://arxiv.org/abs/1606.04080 >.

Yamins, D. - DiCarlo, J. (2016): Using goal-driven deep learning models to understand sensory cortex, Nat Neurosci 19, 356-365, dostupné z: < https://doi.org/10.1038/nn.4244 >. 
Zhou, Z-H. (2019): Abductive learning: towards bridging machine learning and logical reasoning, Sci. China Inf. Sci. 62(76101), dostupné z: < https://doi.org/10.1007/s11432-018-9801$4>$.

Toto dílo lze užít v souladu s licenčními podmínkami Creative Commons BY-NC-ND 4.0 International (https://creativecommons.org/licenses/by-nc-nd/4.0/legalcode). Uvedené se nevztahuje na díla či prvky (např. obrazovou či fotografickou dokumentaci), které jsou v díle užity na základě smluvní licence nebo výjimky či omezení př́íslušných práv. 